\title{
Winter color polymorphisms identify global hot spots for evolutionary rescue from climate change
}

\author{
L. Scott Mills, ${ }^{1,2 *+}$ Eugenia V. Bragina, ${ }^{2+}$ Alexander V. Kumar,,${ }^{2,3}$ Marketa Zimova, ${ }^{2,3}$ Diana J. R. Lafferty, ${ }^{2,3}$ \\ Jennifer Feltner, ${ }^{,, 3}$ Brandon M. Davis, ${ }^{2,3}$ Klaus Hackländer, ${ }^{2,4}$ Paulo C. Alves, ${ }^{3,5,6}$ Jeffrey. M. Good, ${ }^{7}$ \\ José Melo-Ferreira, ${ }^{5,6}$ Andreas Dietz, ${ }^{8}$ Alexei V. Abramov, ${ }^{9}$ Natalia Lopatina, ${ }^{10}$ Kairsten Fay $^{2}$
}

${ }^{1}$ Wildlife Biology Program and Office of the Vice President for Research and Creative Scholarship, University of Montana, Missoula, MT 59812, USA. ${ }^{2}$ Fisheries, Wildlife, and Conservation Biology Program, Department of Forestry and Environmental Resources, North Carolina State University, Raleigh, NC 27695, USA. ${ }^{3}$ Wildlife Biology Program, University of Montana, Missoula, MT 59812, USA. ${ }^{4}$ Institute of Wildlife Biology and Game Management, BOKU - University of Natural Resources and Life Sciences, Vienna, Austria. ${ }^{5} \mathrm{CIBIO}$, Centro de Investigação em Biodiversidade e Recursos Genéticos, InBIO Laboratório Associado, Universidade do Porto, Campus Agrário de Vairão, $4485-661$ Vairão, Portugal. ${ }^{6}$ Departamento de Biologia, Faculdade de Ciências da Universidade do Porto, Rua do Campo Alegre 4169-007 Porto, Portugal. ${ }^{7}$ Division of Biological Sciences, University of Montana, Missoula, MT 59812, USA. ${ }^{8}$ German Aerospace Center, Earth Observation Center, German Remote Sensing Data Center, Oberpfaffenhofen, Wessling 82234, Germany. ${ }^{9}$ Zoological Institute, Russian Academy of Science, Saint Petersburg 199034, Russia. ${ }^{10}$ Institute of Systematics and Ecology of Animals SB RAS, Novosibirsk, 630091, Russia.

*Corresponding author. Email: scott.mills@umontana.edu

tThese authors contributed equally to this work.

Maintenance of biodiversity in a rapidly changing climate will depend on the efficacy of evolutionary rescue, whereby population declines due to abrupt environmental change are reversed by shifts in genetically driven adaptive traits. However, a lack of traits known to be under direct selection by anthropogenic climate change has limited the incorporation of evolutionary processes into global conservation efforts. In 21 vertebrate species, some individuals undergo a seasonal color molt from summer brown to winter white as camouflage against snow, while other individuals remain brown. Seasonal snow duration is decreasing globally, and fitness is lower for winter white animals on snowless backgrounds. Based on $\mathbf{2 7 1 3}$ georeferenced samples of known winter coat color-from eight species across trophic levels-we identify environmentally driven clinal gradients in winter coat color, including polymorphic zones where winter brown and white morphs co-occur. These polymorphic zones, underrepresented by existing global protected area networks, indicate hot spots for evolutionary rescue in a changing climate.

The significance of evolution in fostering the persistence of species facing rapid environmental change is a fundamental tenet of biology that underlies the modern field of conservation biology (1-3). Despite the central role of evolution for maintaining biodiversity, criteria to facilitate adaptation by wild species remain largely absent from conservation planning $(4,5)$. This is a particularly acute omission in a rapidly changing climate $(6,7)$ where evolutionary rescue may reverse population declines via adaptive evolutionary change in phenotypes $(2,8,9)$.

As a first step to demonstrate how evolutionary rescue might enter conservation planning for climate change, we describe a fitness-relevant trait that exhibits clines of locally adapted morphs shaped directly by climate. At least 21 bird and mammal species undergo photoperiod-induced seasonal coat color molts from brown to white in some portions of their range to maintain crypsis against seasonal snow presence or absence (Table 1). This seasonal phenological trait is confronting decreased seasonal snow cover duration, one of the most persistent and widespread signals of climate change
$(10,11)$. Field studies show that winter white animals mismatched against snowless ground suffer a high fitness costs due to increased predator-caused mortality, which in the absence of evolutionary shifts would result in substantial population declines (12). In fact, coat color mismatch against decreased snow duration may have already contributed to range contractions for several species (13-16).

Although the seasonal brown-white-brown color trait is a classic polyphenism-whereby multiple morphs are produced by a single individual (17)-individuals in some populations molt to brown winter coats, thereby not undergoing the circannual color change. This intra-specific variation results in monomorphic winter white and brown populations, but also in polymorphic populations that include sympatric winter white and brown color morphs. Importantly, this phenotypic variation is genetically determined: latitudinal transplants, common garden, and breeding experiments with several seasonal color molting species have consistently showed minimal plasticity in the expression of winter phenotype and instead suggested a simple genetic basis involving 
one or a few major loci [e.g., (18-22)].

The enhanced standing phenotypic variation fostered by genetically based polymorphisms have long been linked to individual fitness and to potential for evolution to rescue populations from abrupt environmental change (23, 24). Specifically, color polymorphisms have served as powerful models demonstrating evolution in nature, including iconic examples of evolutionary response to anthropogenic stressors (25-28). For the seasonal coat color trait, selection is expected to act on all winter color morphs based on local snow duration, but evolutionary rescue to changing climate should be enhanced by polymorphic regions where both brown and white winter morphs co-occur.

Here we use a hierarchical approach across organismal scales (individual, population, species) to spatially map geographic clines in winter coat color against local climate variables (29). We collated georeferenced descriptions of winter coat color from 2,713 specimens spanning 60 countries across species ranges, with data sources including published accounts and specimens at 26 museums globally (table S1). From these georeferenced winter color morph samples, we built predictive models of winter color phenotypes across geographic ranges for 8 mammal species that span trophic levels: 4 hare species and 4 carnivore species (3 weasels and Arctic fox).

The response variable for our global generalized mixed model was the probability of an individual having a winter white coat, with species as a random effect and fixed effects including climate and landscape-level covariates (table S2). As expected for a trait under selection for crypsis against snow or bare ground, the most important covariates emerging from the global model were snow cover duration and two climate variables affecting snow seasonality and transience. The probability of being white in winter (as opposed to brown) increased positively with snow duration and with seasonality (ranges of mean monthly temperatures; BIO2), and negatively with isothermality (BIO3; an index of snow transience).

Using the 3 environmental covariates identified in the best-fitting model, we created for each of the 8 species a predictive range-wide map that assigned to each pixel a probability of an individual being white in winter (Fig. 1 and figs. S1 to S8). Based on five-fold cross validation, models fit georeferenced winter color morph data well (29). Across species, clinal gradients in winter color follow expected environmental gradients based on snow duration and ephemerality: winter white morphs were more likely in regions with more persistent snowpack that tended to be more northern, higher elevation, and less maritime (Fig. 1). These results suggest that strong natural selection for camouflage against varying snow duration underlies phenotypic variation in winter color morphs across environmental gradients.
To identify hot spots that foster evolutionary rescue, we converted the continuous probabilities of individuals being winter white (versus brown) into polymorphic zones, using both a narrow $(40 \%<\mathrm{P}$ [winter white $<60 \%)$ and broad $(20 \%<\mathrm{P}$ [winter white $<<0 \%)$ criteria. Depending on the species and criteria, polymorphic zones comprised $1 \%$ to $57 \%$ of a species range (table S4). The species with the most widespread polymorphic zones (for Narrow/Broad criteria) are arctic fox (10\%/57\%), white-tailed jackrabbit (13\%/43\%), and long-tailed weasel $(9 \% / 33 \%)$. Mountain hares have the most restricted polymorphic zone ( $1 \% / 2 \%)$.

Given that the clinal gradient of winter color represents fine-tuned adaptation to local snow conditions, how must winter phenotypes shift to adaptively track projected reductions in snow duration? Based on our model, we plotted the current probabilities of being white in winter against snow duration for 4 species (table S6) to characterize 'optimal' winter coat color as shaped by past selection (Fig. 2). Depending on the species and snow duration, a plausible reduction of 30-50 days of seasonal snow cover during this century (30) would require many winter white populations to become polymorphic and polymorphic populations to become winter brown to maintain optimal winter coat colors.

Next, we combined the polymorphic zones of the 8 species to identify regions with multispecies polymorphic zones (Fig. 3). Although under the broad criteria two or more species shared putative polymorphic zones across much of the northern hemisphere (Fig. 3, A and B), narrow criteria multispecies polymorphic zones were limited to a few regions in North America (Fig. 3C) and Great Britain (Fig. 3D).

Polymorphic zones within and across these 8 species ranges identify regions that currently hold disproportionately high potential to initiate evolutionary rescue from camouflage mismatch in this fitness relevant trait impacted by climate change. In addition to being hot spots for in situ evolutionary rescue, these areas may also facilitate gene flow of adaptive alleles to monomorphic populations $(31,32)$.

While protected areas cover $13 \%$ of the world's terrestrial area (33), multispecies polymorphic zones are poorly represented by existing protected areas (table S5). Even under our broad criteria, only $5 \%$ of multispecies polymorphic zones occur in the most strict protected areas described by IUCN [categories I and II; (34)]; all six IUCN categories of protected areas combined embrace only $10 \%$ of multispecies polymorphic zones (for the narrowly defined polymorphic zones: $4 \%$ fall in strict and $7 \%$ in all) (table S5).

The broad geographic ranges of color molting species, and their roles as flagships and strongly interacting predators and prey, amplify the value of understanding how climate mediated evolution may foster their persistence in the face of climate change. Failed adaptation by these species could have indirect impacts that reverberate through their ecosystems. 
Further, because the co-distributed species that make up the multispecies polymorphic zones represent both predators (e.g., weasels, Arctic fox) and prey (e.g., hares), differential molt responses in different species could exacerbate fitness costs and create cascading co-evolutionary outcomes.

Mismatch in seasonal coat color provides a visual metaphor for how climate change may affect biodiversity, and regions of sympatric winter color polymorphisms identify multispecies hot spots for evolutionary rescue in the face of reduced snow duration. Our framework to identify zones of enhanced potential to initiate evolutionary rescue from climate change could be applied to polymorphisms in other morphological or physiological traits affected by climate change. Identification of hot spots for evolutionary rescue provides novel opportunities to integrate evolutionary processes to conservation planning in a changing climate.

\section{REFERENCES AND NOTES}

1. J. Huxley, Morphism and evolution. Heredity 9, 1-51 (1955).

2. E. Vander Wal, D. Garant, M. Festa-Bianchet, F. Pelletier, Evolutionary rescue in vertebrates: Evidence, applications and uncertainty. Philos. Trans. R. Soc. Lond. B Biol. Sci. 368, 20120090 (2013). Medline

3. M. E. Soulé, O. H. Frankel, Conservation and Evolution (Cambridge Univ. Press, Cambridge, 1981).

4. IUCN, "Standard for the identification of key biodiversity areas, Version 1." (IUCN, Gland, Switzerland, 2015).

5. C. R. Margules, R. L. Pressey, Systematic conservation planning. Nature 405, 243253 (2000). Medline

6. S. Lavergne, M. E. K. Evans, I. J. Burfield, F. Jiguet, W. Thuiller, Are species' responses to global change predicted by past niche evolution? Philos. Trans. $R$. Soc. Lond. B Biol. Sci. 368, 20120091 (2013). Medline

7. T. P. Dawson, S. T. Jackson, J. I. House, I. C. Prentice, G. M. Mace, Beyond predictions: Biodiversity conservation in a changing climate. Science 332, 53-58 (2011). Medline

8. A. Gonzalez, O. Ronce, R. Ferriere, M. E. Hochberg, Evolutionary rescue: An emerging focus at the intersection between ecology and evolution. Philos. Trans. R. Soc. Lond. B Biol. Sci. 368, 20120404 (2013). Medline

9. S. M. Carlson, C. J. Cunningham, P. A. H. Westley, Evolutionary rescue in a changing world. Trends Ecol. Evol. 29, 521-530 (2014). Medline

10. N. S. Diffenbaugh, C. B. Field, Changes in ecologically critical terrestrial climate conditions. Science 341, 486-492 (2013). Medline

11. K. E. Kunkel, D. A. Robinson, S. Champion, X. Yin, T. Estilow, R. M. Frankson, Trends and extremes in Northern Hemisphere snow characteristics. Curr. Clim. Change Rep. 2, 65-73 (2016).

12. M. Zimova, L. S. Mills, J. J. Nowak, High fitness costs of climate change-induced camouflage mismatch. Ecol. Lett. 19, 299-307 (2016). Medline

13. S. M. Sultaire, J. N. Pauli, K. J. Martin, M. W. Meyer, M. Notaro, B. Zuckerberg, Climate change surpasses land-use change in the contracting range boundary of a winter-adapted mammal. Proc. R. Soc. London Ser. B 283, 20153104 (2016). Medline

14. D. R. Diefenbach, S. L. Rathbun, J. K. Vreeland, D. Grove, W. J. Kanapaux, Evidence for range contraction of snowshoe hare in Pennsylvania. Northeast. Nat. (Steuben) 23, 229-248 (2016)

15. S. Imperio, R. Bionda, R. Viterbi, A. Provenzale, Climate change and human disturbance can lead to local extinction of Alpine rock ptarmigan: New insight from the western Italian Alps. PLOS ONE 8, e81598 (2013). Medline

16. S. Pedersen, M. Odden, H. C. Pedersen, Climate change induced molting mismatch? Mountain hare abundance reduced by duration of snow cover and predator abundance. Ecosphere 8, 1234 (2017).

17. E. Mayr, Animal Species and Evolution (The Belknap Press of Harvard University
Press, Cambridge, MA, 1963).

18. E. R. Hall, American weasels. Univ. Kans. Publ. Mus. Nat. Hist. 4, 1-466 (1951).

19. R. M. Hansen, G. D. Bear, Winter coats of white-tailed jackrabbits in Southwestern Colorado. J. Mammal. 44, 420-422 (1963).

20. M. S. Ferreira, P. C. Alves, C. M. Callahan, J. P. Marques, L. S. Mills, J. M. Good, J. Melo-Ferreira, The transcriptional landscape of seasonal coat colour moult in the snowshoe hare. Mol. Ecol. 26, 4173-4185 (2017). Medline

21. D. I. Våge, E. Fuglei, K. Snipstad, J. Beheim, V. M. Landsem, H. Klungland, Two cysteine substitutions in the MC1R generate the blue variant of the Arctic fox (Alopex lagopus) and prevent expression of the white winter coat. Peptides 26 1814-1817 (2005). Medline

22. A. Bergengren, On genetics, evolution and history of distribution of the heath-hare: A distinct population of the arctic hare, Lepus timidus. Viltrevy (Stockh.) 6, 380460 (1969).

23. A. Forsman, Is colour polymorphism advantageous to populations and species? Mol. Ecol. 25, 2693-2698 (2016). Medline

24. L. Wennersten, A. Forsman, Population-level consequences of polymorphism, plasticity and randomized phenotype switching: A review of predictions. Biol. Rev. Camb. Philos. Soc. 87, 756-767 (2012). Medline

25. T. Caro, The adaptive significance of coloration in mammals. Bioscience 55, 125136 (2005).

26. M. Stevens, S. Merilaita, Animal camouflage: Current issues and new perspectives. Philos. Trans. R. Soc. Lond. B Biol. Sci. 364, 423-427 (2009). Medline

27. E. B. Ford, Polymorphism. Biol. Rev. Camb. Philos. Soc. 20, 73-88 (1945),

28. I. J. Saccheri, F. Rousset, P. C. Watts, P. M. Brakefield, L. M. Cook, Selection and gene flow on a diminishing cline of melanic peppered moths. Proc. Natl. Acad. Sci. U.S.A. 105, 16212-16217 (2008). Medline

29. Materials and methods are available as supplementary materials.)

30. L. S. Mills, M. Zimova, J. Oyler, S. Running, J. T. Abatzoglou, P. M. Lukacs, Camouflage mismatch in seasonal coat color due to decreased snow duration. Proc. Natl. Acad. Sci. U.S.A. 110, 7360-7365 (2013). Medline

31. L. Hannah, L. Flint, A. D. Syphard, M. A. Moritz, L. B. Buckley, I. M. McCullough, Fine-grain modeling of species' response to climate change: Holdouts, steppingstones, and microrefugia. Trends Ecol. Evol. 29, 390-397 (2014). Medline

32. A. Hampe, A. S. Jump, Climate relicts: Past, present, future. Annu. Rev. Ecol. Evol. Syst. 42, 313-333 (2011).

33. B. Bertzky et al., "Protected Plant Report 2012: Tracking progress towards global targets for protected areas," IUCN, Gland, Switzerland and UNEP-WCMC Cambridge, UK, 2012)

34. A. Pfaff, F. Santiago-Ávila, L. Joppa, Evolving protected-area impacts in Mexico: Political shifts as suggested by impact evaluations. Forests 8, 17 (2016).

35. X. Xu, G. X. Dong, X. S. Hu, L. Miao, X. L. Zhang, D. L. Zhang, H. D. Yang, T. Y. Zhang, Z. T. Zou, T. T. Zhang, Y. Zhuang, J. Bhak, Y. S. Cho, W. T. Dai, T. J. Jiang, C. Xie, R. Li, S. J. Luo, The genetic basis of white tigers. Curr. Biol. 23, 1031-1035 (2013). Medline

36. C. R. Camargo, E. Colares, A. M. L. Castrucci, Seasonal pelage color change: News based on a South American rodent. An. Acad. Bras. Cienc. 78, 77-86 (2006) Medline

37. A. V. Kumar, Effects of a dynamic forest structure on vital rates, behavior and the seasonal molt of the snowshoe hare, Thesis, North Carolina State University, Raleigh, NC (2016).

38. A. J. Dietz, C. Kuenzer, S. Dech, Global SnowPack: A new set of snow cover parameters for studying status and dynamics of the planetary snow cover extent. Remote Sens. Lett. 6, 844-853 (2015).

39. D. K. Hall, G. A. Riggs, MODIS/Terra Snow Cover Daily L3 Global 500 m Grid, Version 6. [Sept. 1st, 2000 - Aug. 31st, 2015]. Boulder, Colorado USA. NASA National Snow and Ice Data Center Distributed Active Archive Center. Date Accessed: May 24, 2017; doi: http://dx.doi.org/10.5067/MODIS/MOD10A1.006

40. R. J. Hijmans, S. E. Cameron, J. L. Parra, P. G. Jones, A. Jarvis, Very high resolution interpolated climate surfaces for global land areas. Int. J. Climatol. 25, 1965-1978 (2005).

41. M. S. O'Donnell, D. A. Ignizio, Bioclimatic predictors for supporting ecological applications in the conterminous United States. U.S. Geol. Surv. Data Ser. 691, 10 (2012).

42. D. Bates et al., Package "Ime4" (2014), pp. 1-113 
43. M. Stone, An asymptotic equivalence of choice of model by cross-validation and Akaike's criterion. J. R. Stat. Soc. B 39, 44-47 (1977).

44. R. Maggini, A. Lehmann, N. E. Zimmermann, A. Guisan, Improving generalized regression analysis for the spatial prediction of forest communities. J. Biogeogr. 33, 1729-1749 (2006).

45. L. Joppa, A. Pfaff, Reassessing the forest impacts of protection: The challenge of nonrandom location and a corrective method. Ann. N. Y. Acad. Sci. 1185, 135-149 (2010). Medline

46. A. Nelson, K. M. Chomitz, Effectiveness of strict vs. multiple use protected areas in reducing tropical forest fires: A global analysis using matching methods. PLOS ONE 6, e22722 (2011). Medline

\section{ACKNOWLEDGMENTS}

We thank S. T. Giery, D. Emlen, and four anonymous reviewers for insightful comments on the manuscript. We also thank museum curators (table S1) and substantial sample contributions from K. Zub, K. Garrison, T. Berry, J. Dines, E. M. Fouts, K. Nicholson, D. Oehlschlager, C. Opitz, A. M. Riedel, B. Wommack, S. Lado, M. Jones, J. Ivan, J. Whittington, and A. Angerbjörn. Funding: L.S.M.: National Science Foundation Division of Environmental Biology Grant 0841884; A.V.K.: National Science Foundation Graduate Research Fellowship under grant no. DGE-1252376; P.C.A.: FLAD, Luso-American Development Foundation; M.Z.: The Department of the Interior Southeast Climate Science Center Global Change Fellowship (Cooperative Agreement No. G10AC00624); J.M.F.: Fundação para a Ciência e a Tecnologia Grants "CHANGE" PTDC/BIA-EVF/1624/2014

(Portuguese national funds) and IF/00033/2014/CP1256/CT0005 Investigador FCT (POPH-QREN funds from ESF and MCTES), and SYNTHESYS grant SE-TAF4695 (EU FP7; agreement 226506) to access the Swedish Museum of Natural History; J.M.G.: National Science Foundation EPSCoR grant 1736249; N.L.: Russian Foundation for Basic Research [17-04-00269 A]. Author contributions: L.S.M. conceived the idea, helped with analysis, and led the writing. E.B., along with A.V.K., led the data analysis, contributed conceptually, and helped with writing. M.Z. helped with data analysis, figures, writing, and contributed conceptually. D.J.R.L., J.F., B.M.D., K.H., P.C.A., J.M.G., and J.M.F. contributed conceptually and with writing. A.D., A.V.A., N.L., and K.F. helped provide key input data. All authors read and approved the submitted manuscript. Competing interests: None declared. Data and materials availability: The data reported in the paper are available in the supplementary materials and archived in the Dryad Digital Repository: https://doi.org/10.5061/dryad.8m0pl. Global SnowPack data are available as WMS at DLR (German Aerospace Center) Geoservice: https://geoservice.dlr.de.

\section{SUPPLEMENTARY MATERIALS}

www.sciencemag.org/cgi/content/full/science.aan8097/DC1

Materials and Methods

Figs. $\mathrm{S} 1$ to $\mathrm{S} 8$

Tables S1 to S6

References (35-46)

1 June 2017; accepted 2 January 2018

Published online 15 February 2018

10.1126/science.aan8097 


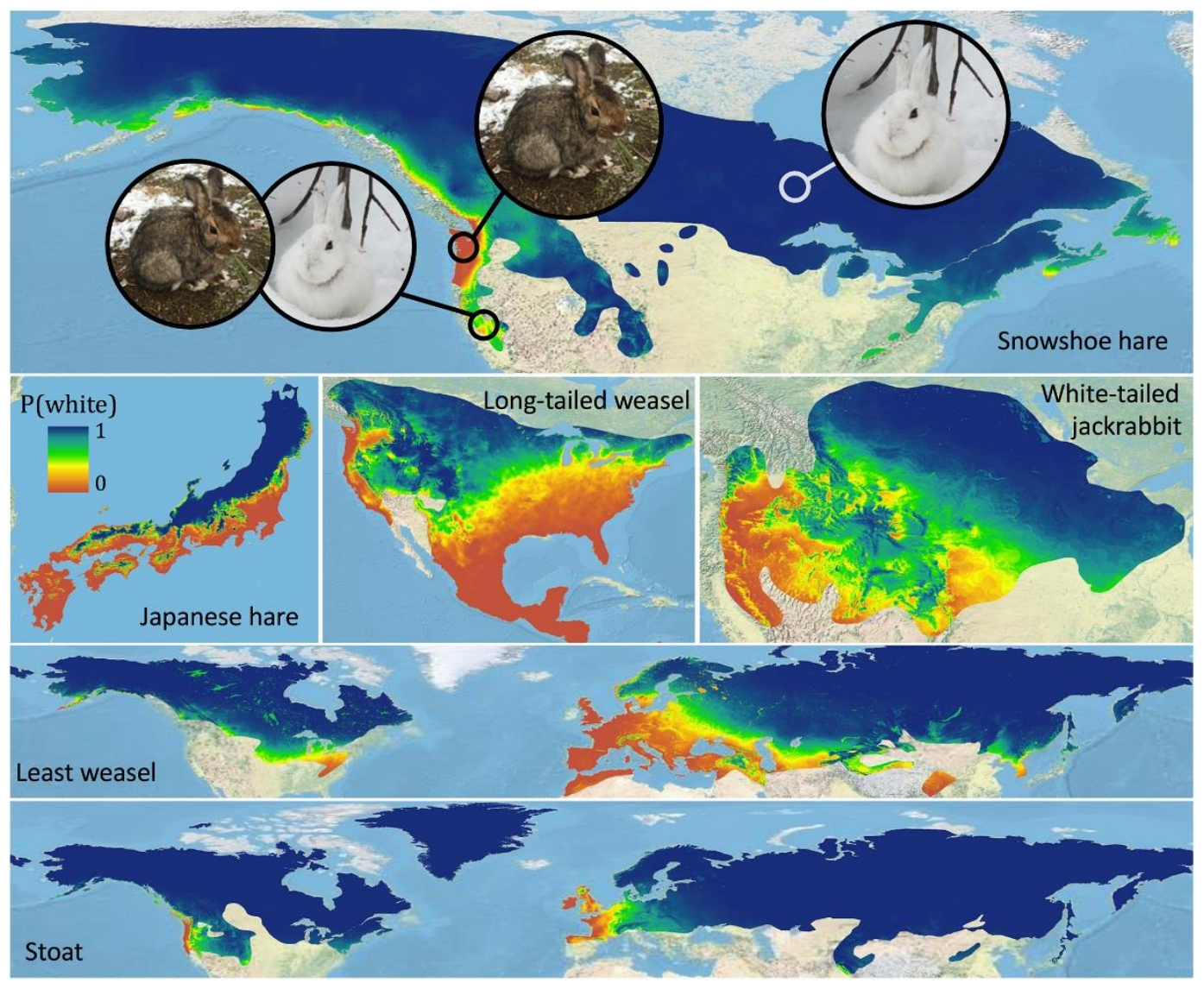

Fig. 1. Clinal variation in winter color phenotypes for six mammal species. Colder colors (e.g., blue) indicate higher probability of winter white morphs (denoted by photo of a winter white snowshoe hare); warmer colors (e.g., orange) indicate higher probability of winter brown morphs (denoted by brown snowshoe hare); and greenish/yellow colors indicate polymorphic populations (see figs. S1 to S8 for larger versions of these maps and for maps of Arctic fox and mountain hare). [Photo credits: L. S. Mills research archives] 


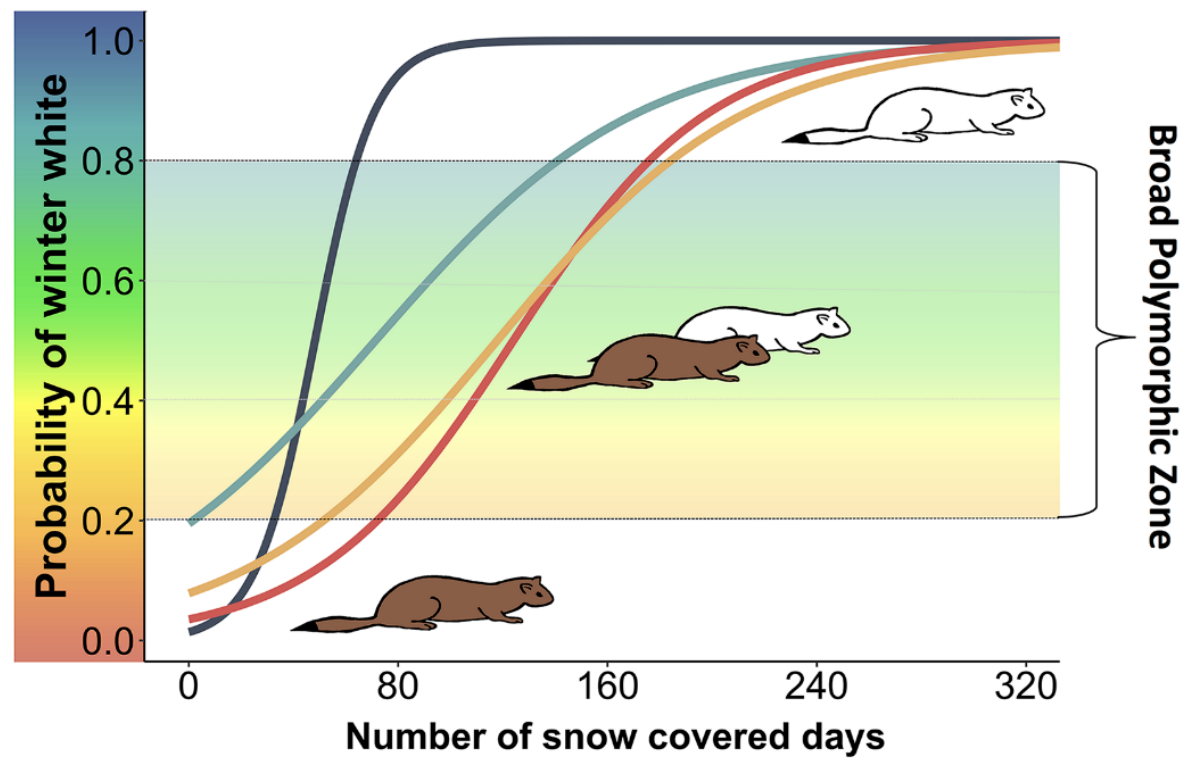

Fig. 2. Change in probability of being winter white as snow duration changes for four molting species (Japanese hare: dark blue, white-tailed jackrabbit: light blue, least weasel: yellow, long-tailed weasel: red). The central colored area with both winter white and brown animals represents our broadly defined polymorphic zone (i.e., 20\% < P [winter white] < 80\%). 

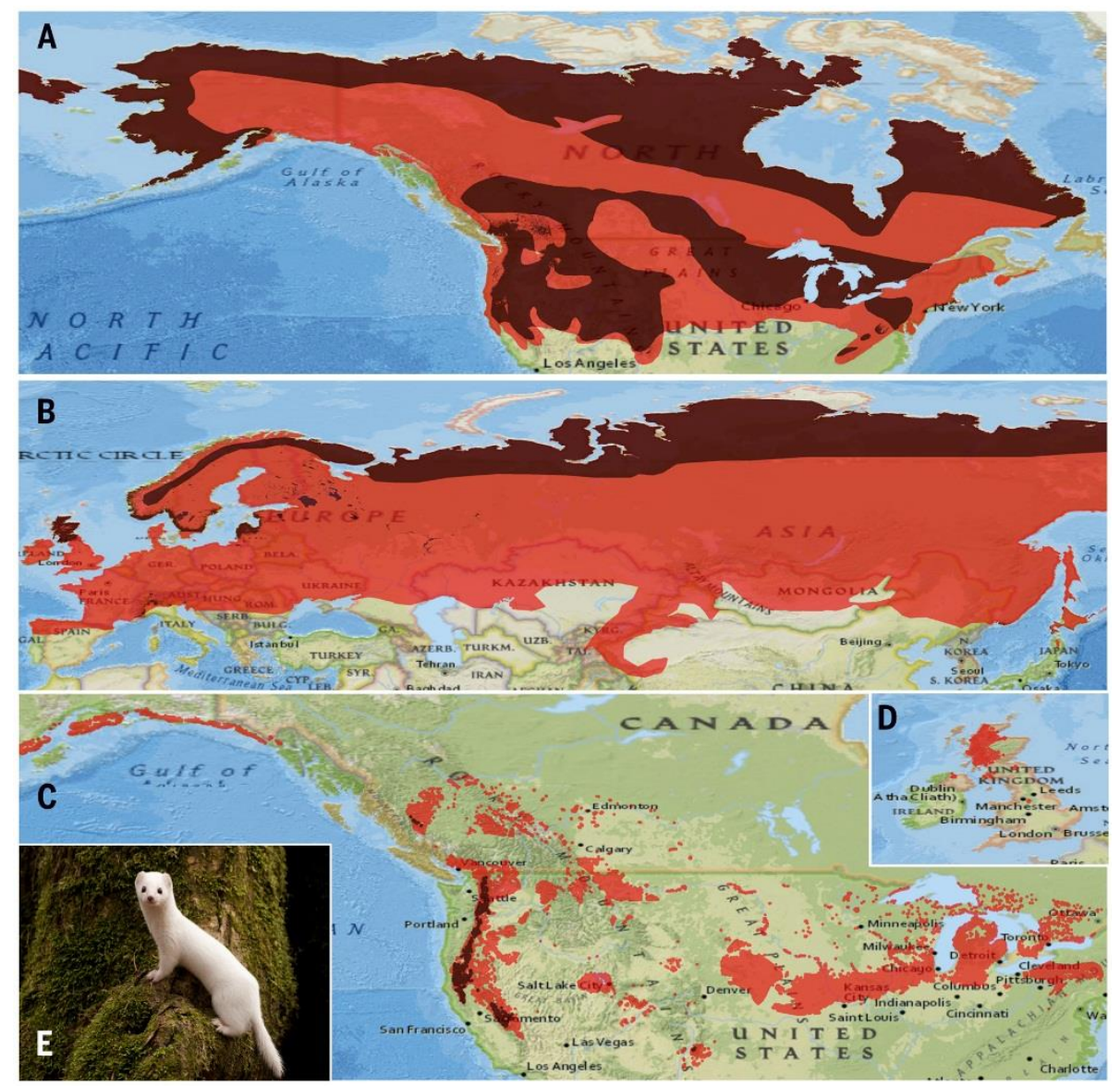

Fig. 3. Regions with polymorphisms in winter coat color for multiple species. Panels indicate where polymorphic zones overlap for two (red) or three (brown) species, derived from predictive maps for 8 species (see Fig. 1). Polymorphic zones defined broadly as $20 \%<P$ [winter white] $<80 \%$ in (A) North America and (B) Eurasia. (C) Polymorphic zones defined more narrowly as $40 \%<P$ [winter white] $<60 \%$; found only in North America and (D) Great Britain. (E) Example of camouflage mismatch [least weasel photo credit: Karol Zub]; in polymorphic zones as snow duration decreases, mismatched winter white morphs would be selected against in favor of the sympatric winter brown morphs. 
Table 1. The 21 vertebrate species known to exhibit seasonal coat color molt. The first 8 species are those with sufficient sample sizes of georeferenced winter color phenotype to model range-wide distribution of color morphs. The other 13 species are those known to undergo seasonal coat color change in at least some populations. Species taxonomy follows the IUCN red list.

\begin{tabular}{|c|c|c|c|}
\hline FAMILY/Species & Museums & $\begin{array}{l}\text { npled specimens } \\
\text { Literature, citizen } \\
\text { science, trapping } \\
\text { records, etc. }\end{array}$ & TOTAL \\
\hline \multicolumn{4}{|l|}{ LEPORIDAE } \\
\hline Snowshoe hare (Lepus americanus) & 335 & 132 & 467 \\
\hline White-tailed jackrabbit (Lepus townsendii) & 130 & 14 & 144 \\
\hline Mountain hare (Lepus timidus) & 149 & 74 & 223 \\
\hline $\begin{array}{l}\text { Japanese hare (Lepus brachyurus) } \\
\text { MUSTELIDAE }\end{array}$ & 8 & 54 & 62 \\
\hline $\begin{array}{l}\text { Short-tailed weasel/stoat/ermine } \\
\text { (Mustela erminea) }\end{array}$ & 623 & 32 & 655 \\
\hline Long-tailed weasel (Mustela frenata) & 444 & 36 & 480 \\
\hline $\begin{array}{l}\text { Least weasel (Mustela nivalis) } \\
\quad \text { CANIDAE }\end{array}$ & 606 & 30 & 636 \\
\hline Arctic fox (Vulpes lagopus) & 26 & 20 & 46 \\
\hline OVERALL SAMPLE SIZE & 2321 & 392 & 2713 \\
\hline
\end{tabular}

\section{OTHER KNOWN COLOR-CHANGING SPECIES}

MURIDAE: Siberian [Djungarian] hamster (Phodopus sungorus); Collared lemming (Dicrostonyx groenlandicus); Wrangel Island collared lemming (Dicrostonyx vinogradovi); Palearctic collared lemming (Dicrostonyx torquatus); Ungava collared lemming (Dicrostonyx hudsonius); Richardson's collared lemming (Dicrostonyx richardsoni); Nelson's collared lemming (Dicrostonyx nelsoni); Ogilvie mountains collared lemming (Dicrostonyx nunatakensis)

LEPORIDAE: Arctic hare (Lepus arcticus), Alaskan hare (Lepus othus)

TETRAONIDAE: Rock ptarmigan (Lagopus muta); White-tailed ptarmigan (Lagopus leucurus); Willow ptarmigan (Lagopus lagopus) 